\title{
RADIOCARBON DATING OF COPPER-PRESERVED ORGANICS
}

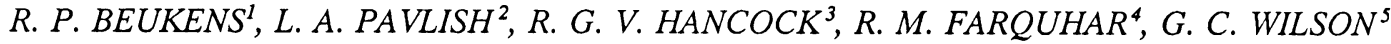 \\ P. J. JULIG ${ }^{6}$ and WILLIAM ROSS ${ }^{7}$
}

ABSTRACT. The small but vital role of ${ }^{14} \mathrm{C}$ dating in archaeometric research is clearly shown in the copper project reported herein. The ${ }^{14} \mathrm{C}$ ages place a time perspective on the "Old Copper Culture Complex," substantiating early Libby dates that had been questioned. The respective roles of INAA, PGE and Pb isotope work are briefly summarized. A long tradition of heat treatment from Paleoindian stone to Archaic copper is suggested.

\section{INTRODUCTION}

The multidisciplinary copper research program reported here was implemented by a consortium of research facilities, universities, private enterprise and government to better characterize copper materials from the Great Lakes Region of North America. The main objectives of the project were:

\section{Non-Destructive Chemical Analyses}

Samples from copper artifacts were obtained from various locations in Ontario and analyzed at the SLOWPOKE Reactor Facility using instrumental neutron activation analyses (INAA). The elemental concentration data were placed in general fields that were predetermined by Hancock et al. (1991a, b) with respect to gold, silver, arsenic and antimony. We clearly separated copper from European and North American origins. Chemical characterization precludes the possibility of accidently mixing European with American materials.

\section{Measurement of Platinum Group Elements}

The IsoTrace Facility analyzed the platinum group element (PGE) distribution in samples of European and North American copper, and the data showed clear separations consistent with those obtained by the SLOWPOKE Reactor Facility. This unique application is believed to be the first use of accelerator mass spectrometry (AMS) for this kind of problem.

\section{Determination of Lead Isotope Ratios}

Copper samples from both European and North American sources were analyzed at the Lead Isotope Laboratory. The resulting data are consistent with the other two elemental analyses and also represent a unique application.

\section{Radiocarbon Dating of Copper-Preserved Organics}

The IsoTrace Facility ${ }^{14} \mathrm{C}$ dated organic materials preserved by copper salts from "Old Copper" artifacts to determine their ages. Copper spear points from the Renshaw and South Fowl Lake sites had preserved cordage, bark twine and wood in their tangs. These materials yielded dates that were internally consistent (Fig. 1; Tables 1,2,3). The samples taken were only of milligram size leaving the remainder for other kinds of analyses. We discuss here the AMS ${ }^{14} \mathrm{C}$ dating of these organic remains.

\footnotetext{
${ }^{1}$ IsoTrace Facility, University of Toronto, Toronto, Ontario, M5S 1A7 Canada

${ }^{2}$ Archaeometry Laboratory, University of Toronto, Toronto, Ontario, M5S 1A7 Canada

${ }^{3}$ SLOWPOKE Reactor Facility, University of Toronto, Toronto, Ontario, M5S 1A4 Canada

${ }^{4}$ Department of Physics, University of Toronto, Toronto, Ontario, M5S 1A7 Canada

${ }^{5}$ Turnstone Geological Services, P. O. Box 130, Station B, Toronto, Ontario, M5T 2T3 Canada

${ }^{6}$ Department of Sociology and Anthropology, Laurentian University, Sudbury, Ontario, P3E 2C6 Canada

'Ontario Ministry of Culture and Communication, Thunder Bay, Ontario, P7E 5N7 Canada
} 
TABLE 1. IsoTrace ${ }^{14} \mathrm{C}$ AMS Results

\begin{tabular}{clccc}
\hline Sample & \multicolumn{1}{c}{ Material } & $\begin{array}{c}\text { Weight } \\
(\mathrm{mg})\end{array}$ & $\begin{array}{c}\text { IsoTrace } \\
(\text { TO no. }\end{array}$ & $\begin{array}{c}{ }^{14} \mathrm{C} \text { age } \\
\text { (yr BP) }\end{array}$ \\
\hline Anderson \#1 & Wood splinter & 12 & -2216 & $5940 \pm 90$ \\
Renshaw \#1 & Plant fiber & 29 & -2213 & $4590 \pm 50$ \\
Renshaw \#2 & Wood fragments & 23 & -2214 & $*$ \\
Renshaw \#3 & Twined cordage & 66 & -2215 & $4630 \pm 60$ \\
Renshaw \#4 & Wood fragments & 30 & -2441 & $4420 \pm 60$ \\
\hline
\end{tabular}

*This sample was lost during laboratory processing.

TABLE 2. Calibrated Age Ranges with Probabilities

\begin{tabular}{|c|c|c|c|}
\hline Probability & $\begin{array}{l}\text { Calibrated age } \\
\quad(\text { cal BC) }\end{array}$ & $\begin{array}{l}\text { 68.3\% Confidence } \\
\text { interval (cal BC) }\end{array}$ & $\begin{array}{l}95.5 \% \text { Confidence } \\
\text { interval (cal BC) }\end{array}$ \\
\hline \multicolumn{4}{|c|}{ Anderson \#1: $5940 \pm 90 \mathrm{BP}$} \\
\hline $62 \%$ & 4930 & $4942-4771$ & $5068-4666$ \\
\hline $100 \%$ & 4892 & $4909-4774$ & $5066-4667$ \\
\hline $100 \%$ & 4885 & $4909-4774$ & $5066-4667$ \\
\hline $100 \%$ & 4842 & $4909-4774$ & $5066-4667$ \\
\hline $100 \%$ & 4809 & $4909-4774$ & $5066-4667$ \\
\hline \multicolumn{4}{|c|}{ Renshaw \#1: $4590 \pm 50 \mathrm{BP}$} \\
\hline $100 \%$ & 3356 & $3374-3338$ & $3383-3299$ \\
\hline \multicolumn{4}{|c|}{ Renshaw \#3: $4630 \pm 60 \mathrm{BP}$} \\
\hline $75 \%$ & 3488 & $3504-3408$ & $3527-3310$ \\
\hline $100 \%$ & 3371 & $3382-3347$ & $3526-3312$ \\
\hline \multicolumn{4}{|c|}{ Renshaw \#4: $4420 \pm 60 \mathrm{BP}$} \\
\hline $55 \%$ & 3250 & $3304-3237$ & $3342-2914$ \\
\hline $100 \%$ & 3085 & $3105-3020$ & $3340-2915$ \\
\hline $100 \%$ & 3071 & $3105-3020$ & $3340-2915$ \\
\hline $100 \%$ & 3039 & $3105-3020$ & $3340-2915$ \\
\hline $74 \%$ & 2945 & $3002-2925$ & $3341-2915$ \\
\hline
\end{tabular}

TABLE 3. Summary of Calibrated Ages

\begin{tabular}{llcccc}
\hline Sample & Material & $\begin{array}{c}\text { IsoTrace } \\
\text { (TO no.) }\end{array}$ & $\begin{array}{c}\text { Calibrated } \\
\text { age (cal BP) }\end{array}$ & $\begin{array}{c}68.3 \% \\
\text { error }\end{array}$ & $\begin{array}{l}95.5 \% \\
\text { error }\end{array}$ \\
\hline Anderson \#1 & Wood splinter & -2216 & 6800 & $+60,-70$ & $+220,-180$ \\
Renshaw \#1 & Plant fiber & -2213 & 5310 & $+20,-20$ & $+30,-60$ \\
Renshaw \#3 & Twined cordage & -2215 & 5320 & $+10,-25$ & $+155,-60$ \\
Renshaw \#4 & Wood fragments & -2441 & 5020 & $+40,-45$ & $+275,-150$ \\
\hline
\end{tabular}




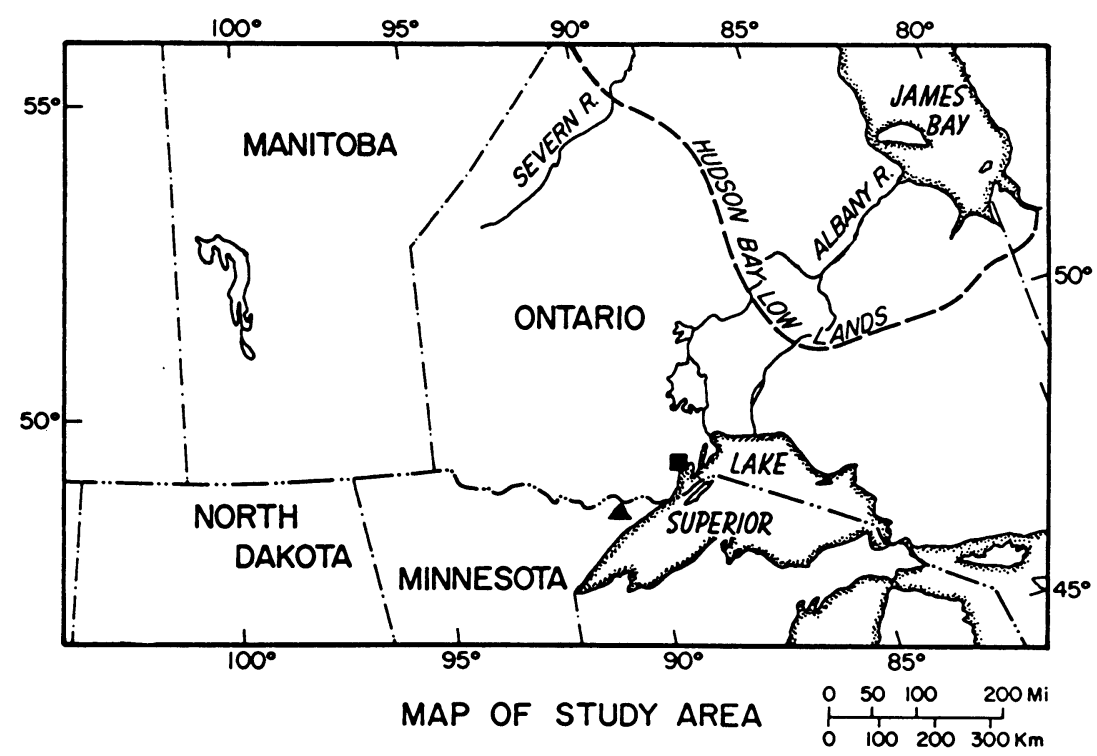

Fig. 1. Map of the research area: $\Delta$ - South Fowl Lake site; $\boldsymbol{-}$ - Renshaw site

\section{BACKGROUND}

Preserved recognizable organic remains are rare in archaeological contexts. An extraordinary environment for the preservation of organic materials is one created by the toxic qualities of copper salts associated with the weathering of copper materials. Under certain conditions, copper artifacts can provide this unique environment of preservation. As a rule, the organics preserved are those encapsulated by, or in close proximity to, copper metal. Thus, the amount of material preserved tends to be very small. Prior to the advent of AMS, small sample size was a deterrent to ${ }^{14} \mathrm{C}$ dating.

Copper materials associated with the "Old Copper" complex or industry, the subject of a long chronological debate (West 1929, 1932; Flaskerd 1940; Miles 1951; Wittry 1951; Griffin 1961, 1964; Giddings 1968), provided the bases for this study. Age determinations attributable to this Archaic-period variant were possible with the advent of ${ }^{14} \mathrm{C}$ dating. Libby (1955) and Ritzenthaler and Wittry (1952) reported the first ${ }^{14} \mathrm{C}$ dates from "Old Copper" cultural material, charred wood directly associated with an Archaic burial from the Oconto site. Libby's early date for the complex (5560 \pm 600 BC (uncalibrated): Sample numbers C-837 and C-839 combined) was questioned by researchers ( $c f$. Johnson 1955; Griffin 1961), but results reported here substantiate his early result.

\section{THE SAMPLES AND THEIR SITES}

Organic materials preserved by copper salts in copper artifacts from the Renshaw and South Fowl Lake archaeological sites provide a unique opportunity to use $\mathrm{AMS}{ }^{14} \mathrm{C}$ dating for gaining insights into ancient humans who occupied what is present-day Ontario (Pavlish \& Banning 1980). We chose samples that contained small amounts of preserved plant material.

\section{South Fowl Lake}

The Fowl Lakes are located on the extreme northeastern boundary of Minnesota and Ontario (Fig. 1). The copper artifacts recovered from the South Fowl Lake site have been attributed to the Old 
Copper Culture Complex, a regional term for an Archaic-period manifestation. One copper sample, named the Anderson point after its collector, had a well-preserved wood splinter lodged in its tang (Platcek 1965).

\section{Renshaw}

The Renshaw archaeological site, DaJi-1 (Canadian Borden No. designation), is one of less than 100 known Archaic-period habitation sites in the western Lake Superior region, and is one of the few to have been excavated. The site is near Thunder Bay, Ontario on a gravel ridge within $1 \mathrm{~km}$ of the present Lake Superior shoreline (Fig. 1).

Four copper samples from the Renshaw site produced close-proximity microenvironments that preserved three associated organic materials. Sample DaJi-1 \#1 is a unilaterally barbed copper harpoon point with a well-preserved plant-fiber binding (hafting?) of bark wrapped around its shaft. Sample DaJi-1 \#2 is a leaf-shaped copper spear point with wood fragments preserved in its tang. Sample DaJi-1 \#3 is a one-of-a-kind small copper toggle-like harpoon spear point with remarkably well-preserved grass-based twined cordage threaded along its internal length (Fig. 2). Sample DaJi-1 \#4 is a spear point with a well-preserved 0.25 -g piece of wood shaft in its tang.

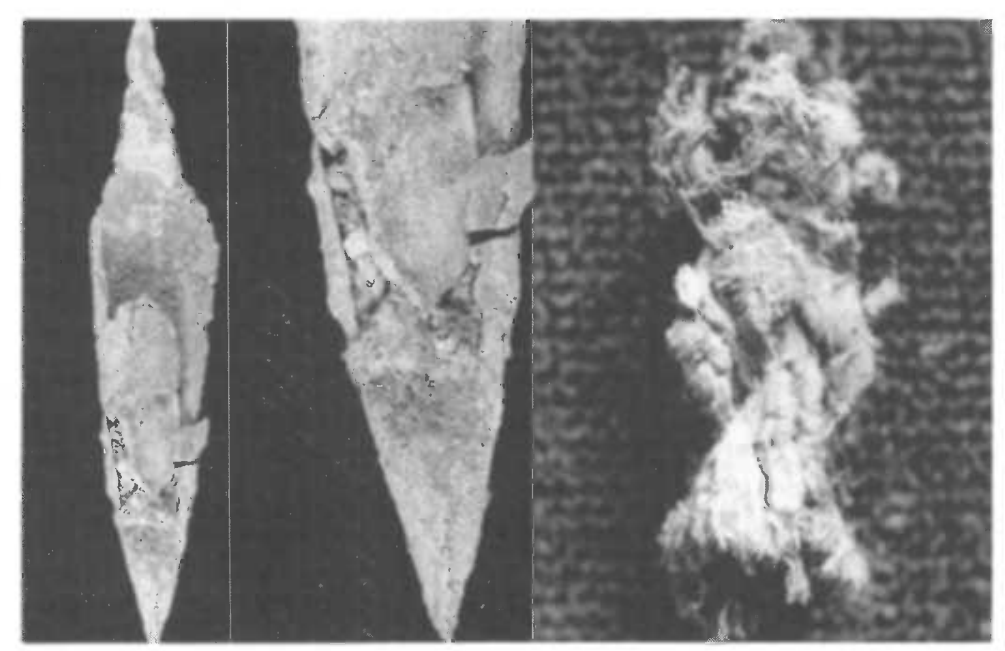

Fig. 2. The harpoon point from the Renshaw site and the location of the cordage are shown along with a closeup of the material after its removal. Only a small portion of the material was required for dating.

\section{ANALYTICAL PROCEDURE}

\section{Sample Processing}

Each sample for ${ }^{14} \mathrm{C}$ dating was physically removed from the copper artifacts with dental tools while being observed under a microscope. The milligram-sized samples were pretreated with the standard acid-alkali-acid (AAA) method to remove all soluble contaminants. The residue was combusted to carbon dioxide in an ampoule combustion system with clean copper oxide and converted to acetylene by lithium carbide synthesis. Electrical dissociation of the acetylene gas in an AC high-voltage discharge produced two graphite targets on 2.5 -mm-diameter aluminum pellets, ready for insertion into the ion source. 


\section{Mass Spectrometric Analyses}

The individual graphite targets were placed on a movable stage (Wilson et al. 1984) in an evacuated sample chamber. The stage has a capacity for 5 samples and 2 reference standards. Only 1 of the 2 machine-ready targets from an individual sample was included in each accelerator run.

Sixteen positions were sequentially sampled on each graphite target. For every position, ${ }^{14} \mathrm{C}$ was measured for $10 \mathrm{~s}$; the ${ }^{12} \mathrm{C}$ and ${ }^{13} \mathrm{C}$ currents were measured before and after. The currents were averaged at every position and the ratios and errors of ${ }^{14} \mathrm{C}$ to ${ }^{12} \mathrm{C}$ and ${ }^{13} \mathrm{C}$ to ${ }^{12} \mathrm{C}$ were determined. The age of the sample was then calculated using the Libby half-life of $5568 \mathrm{yr}$ and expressed in standard ${ }^{14} \mathrm{C}$ yr before present (BP), present being defined as $\mathrm{AD} 1950$. Table 1 presents these results with sample weights (Beukens 1971; Beukens, Gurfinkel \& Lee 1986).

\section{RESULTS AND CONCLUSIONS}

The results in ${ }^{14} \mathrm{C}$ yr cannot be compared directly to calendrical years, as they use the Libby halflife of $5568 \mathrm{yr}$ instead of the actual characteristic half-life of $5730 \mathrm{yr}$, and they do not take into account the variable ${ }^{14} \mathrm{C}$ production due to variations of cosmic-ray intensity. Calibration curves of ${ }^{14} \mathrm{C}$ measurements on dendrochronologically dated wood ranging from $\mathrm{AD} 1950$ to $7000 \mathrm{BC}$ are available (de Jong, Becker \& Mook 1886; Kromer et al. 1986; Linick, Suess \& Becker 1985; Linick et al. 1986; Pearson \& Stuiver 1986; Pearson et al. 1986; Stuiver et al. 1986). Figure 3 shows the section of interest for these copper artifacts produced by C14CAL, an analytical dendrochronological calibration program designed by R. P. Beukens utilizing data provided by Pearson et al. (1986: 911-934); de Jong, Becker and Mook (1986: 939-941) and Kromer et al. (1986: 954-960) for the time regions of interest. The absolute probability as a function of age was calculated from the calibration data, and is presented in Figure 4 for the South Fowl Lake, Anderson Point and Renshaw dates. The solutions with $100 \%$ probability represent those ages where the ${ }^{14} \mathrm{C}$ ages intersect with the calibration curve. As the curve is not a simple linear function, multiple solutions may occur with varying degrees of probability. The most likely solutions (peaks with a probability of greater than 50\%) and their statistical ranges, as derived from the calculated probability as a function of age, are shown in Table 2. By convention, these calibrated ages are expressed in cal $\mathrm{AD}$ or cal $\mathrm{BC}$, to distinguish them from historical ages. Another acceptable way to express them is in calibrated years before present ( $\mathrm{cal} \mathrm{BP}$ ), where present is defined as cal $A D$ 1950.

The direct dating of the organic materials preserved in archaeological copper materials permits ${ }^{14} \mathrm{C}$ dating without questions of context. The results indicate that the Renshaw site materials were last used and deposited between 5 and $5.3 \mathrm{ka} \mathrm{cal} \mathrm{BP}$, and that the Anderson point is $c a .6 .8 \mathrm{ka}$ cal BP. Table 3 shows these results.

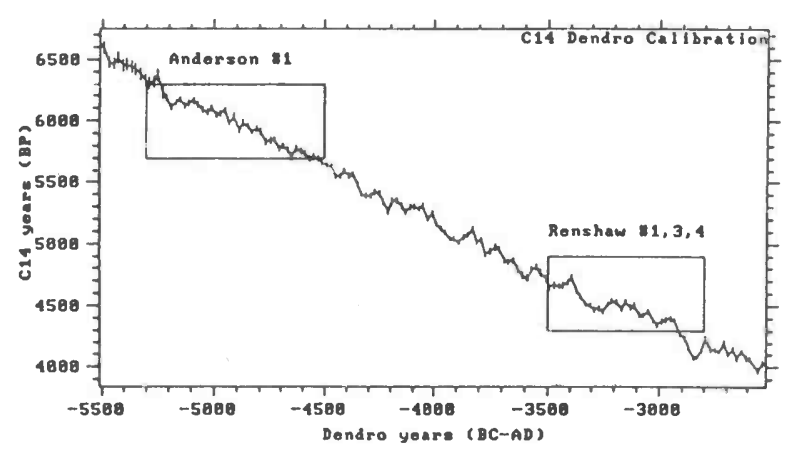

Fig. 3. Part of the dendrochronological calibration curve with the regions of interest emphasized 

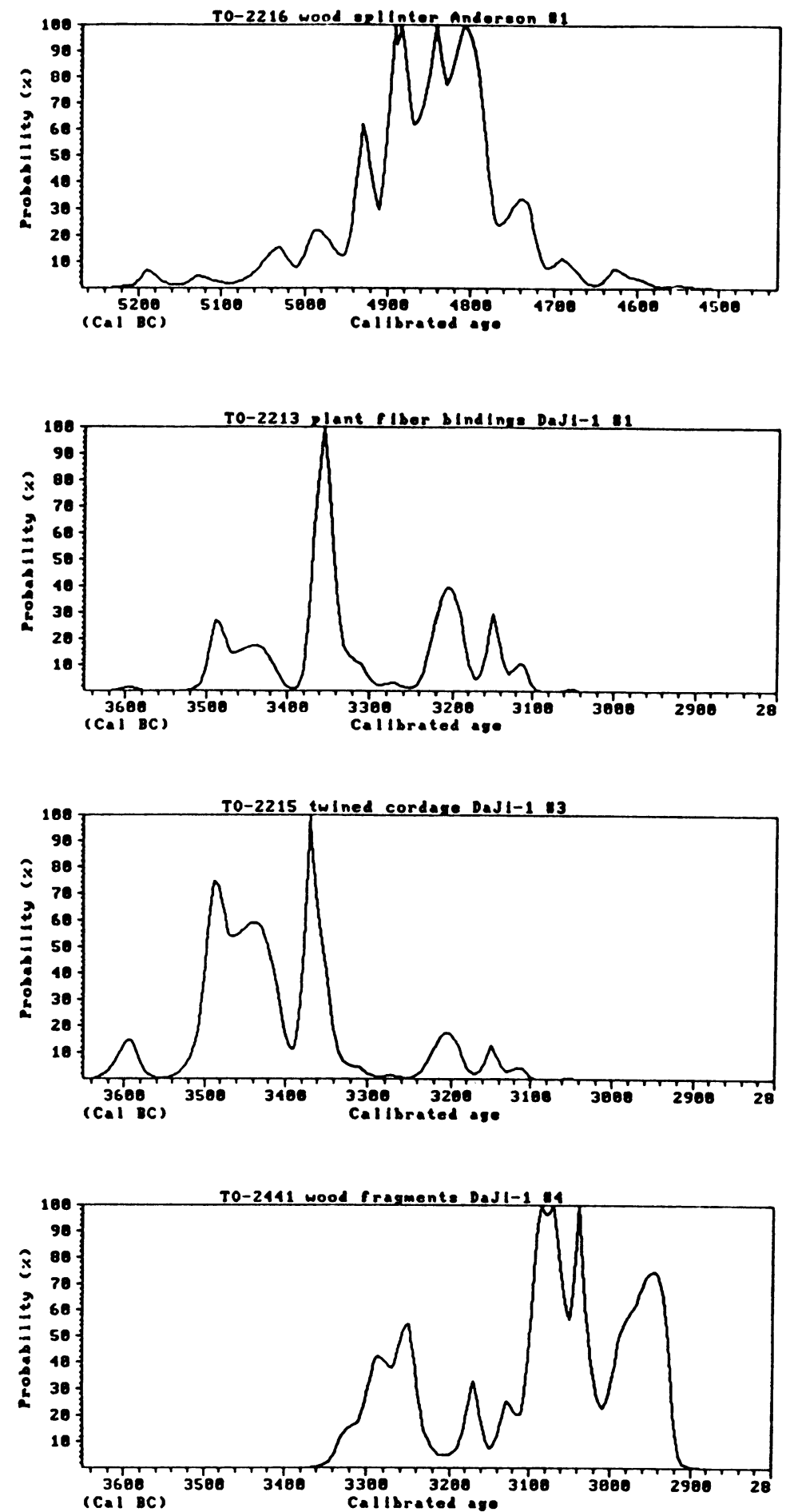

Fig. 4. The probability curves for the intersection of ${ }^{14} \mathrm{C}$ ages with tree-ring ages for the samples analyzed at IsoTrace 
What are the implications of these directly dated copper artifacts? Copper was one of the first metals to be integrated into ancient tool technology. Little evidence exists of Eurasian utilization before smelting processes developed early in the second millennium BC (Tylecote 1987; Renfrew 1973). However, on the basis of the direct date obtained on the Anderson point $(5940 \pm 90)$ (Table 1) (Platcek 1965), the prehistoric populations of the Lake Superior region of North America appear to have been utilizing materials in the Fowl Lakes region on the present-day Minnesota - Ontario border by $c a .7 \mathrm{ka} \mathrm{cal} \mathrm{BP.}$

Prior to this work, most researchers would have attributed the appearance of large utilitarian copper tools to $c a .5 \mathrm{ka}$ cal BP. The direct dating of the Anderson point removes any questions of context association and substantiates the earlier claims for the greater antiquity of copper use in the Lake Superior region. Libby's (1955) early date $(5560 \pm 600 \mathrm{BC})$ for the complex (Ritzenthaler \& Wittry 1952) has been questioned ( $c f$. Johnson 1955; Griffin 1961). Further, that low-temperature annealing had to be used on the otherwise unworkable native copper supports the idea that a long, continuous heat-treating tradition existed in the Great Lakes region of North America (Pavlish \& Sheppard 1983; Purdy 1982).

While the Renshaw ${ }^{14} \mathrm{C}$ ages are not separable at the $95.5 \%$ confidence level (Tables 1,3 ), the preserved wood, bark and grass cordage from the copper materials establishes the antiquity of this component of the site at ca. $5.3 \mathrm{ka}$ cal BP. These results extend evidence for Archaic occupations at the site back by $c a .1 .7 \mathrm{ka}$. A previous estimate, based on a ${ }^{14} \mathrm{C}$-dated hearth feature from the Lake Algoma beach strand, was assumed contemporaneous due to geomorphic association (Arthurs 1979). The age range of occupation at both the South Fowl Lake and the Renshaw sites reaffirm a picture of long, discontinuous occupation by Archaic copper users in the Lake Superior region of North America.

\section{ACKNOWLEDGMENTS}

Our research was made possible by Grant No. 501 from the Ontario Heritage Foundation, Ministry of Citizenship and Culture, Government of Ontario, Canada and by NSERC, the National Science and Engineering Research Council of Canada Infrastructure grant to the SLOWPOKE Reactor Facility.

\section{REFERENCES}

Arthurs, D. (ms.) 1979 An Archaic site on the western Lake Superior shore. Historic Planning and Research, Ministry of Culture and Communication, Government of Ontario, Report on file, Toronto: $35 \mathrm{p}$.

Beukens, R. P. (ms.) 1971 Beschrijving van het programma MINISPEC. Department of Physics, State University of Groningen, The Netherlands, Report IR-99: $32 \mathrm{p}$.

Beukens, R. P., Gurfinkel, D. M. and Lee, H. W. 1986 Progress at the IsoTrace Radiocarbon Facility. In Stuiver, M. and Kra, R. S., eds., Proceedings of the 12th International ${ }^{14} \mathrm{C}$ Conference. Radiocarbon 28(2A): 229-236.

de Jong, A. F. M., Becker, B. and Mook, W. G. 1986 High-precision calibration of the radiocarbon time scale, 3930-3230 cal BC. In Stuiver, M. and Kra, R. S., eds., Proceedings of the 12 th International ${ }^{14} \mathrm{C}$ Conference. Radiocarbon 28(2B): 939-941.

Flaskerd, G. 1940 A metallographic study of certain
Pre-Columbian American implements. American Antiquity 17: 57-60.

Giddings, J. 1968 Ancient Men of the Arctic. London, Secker \& Warburg: XXVIII-XXIX.

Griffin, J. B. 1961 Lake Superior copper and the Indians. Miscellaneous Studies of Great Lakes Prehistory, University of Michigan Anthropology Museum, Anthropology Paper 17: 98 p.

1964 The northeast Woodlands area. In Jennings, J. D. and Norbeck, E., eds., Prehistoric Man in the New World. Chicago, University of Chicago Press: 223-258.

Hancock, R. G. V., Farquhar, R. M., Pavlish, L. A., Salloum, R., Fox, W. A. and Wilson, G. C. 1991a North American native copper and European trade copper analyses. In Pernicka, E. and Wagner, G., eds., Archaeometry '90. Basel, Birkhauser Verlag: 173-182.

Hancock, R. G. V., Pavlish, L. A., Farquhar, R. M., 
Salloum, R., Fox, W. A. and Wilson, G. C. 1991b Distinguishing European and northeastern North American native copper. Archaeometry 33: 69-86.

Johnson, F. 1955 Reflection on the significance of radiocarbon dates. In Libby, W. F., Radiocarbon Dating, 2nd edition. Chicago, University of Chicago Press: 141-161.

Kromer, B., Rhein, M., Bruns, M., Schoch-Fischer, H., Münnich, K. O., Stuiver, M. and Becker, B. 1986 Radiocarbon calibration data for the 6th to the 8th Millennia BC. In Stuiver, M. and Kra, R. S., eds., Proceedings of the 12 th International ${ }^{14} \mathrm{C}$ Conference. Radiocarbon (28)2B: 954-960.

Libby, W. F. 1955 Radiocarbon Dating, 2nd edition. Chicago, University of Chicago Press: $175 \mathrm{p}$.

Linick, T. W., Long, A., Damon, P. E. and Ferguson, C. W. 1986 High-precision radiocarbon dating of bristlecone pine from 6554 to 5350 BC. In Stuiver, M. and Kra, R. S., eds., Proceedings of the 12th International ${ }^{14} \mathrm{C}$ Conference. Radiocarbon (28)2B: 943-953.

Linick, T. W., Suess, H. E. and Becker, B. 1985 La Jolla measurements of radiocarbon in South German oak tree-ring chronologies. Radiocarbon 27(1): 20-32.

Miles, S. W. 1951 A revaluation of the Old Copper Industry. American Antiquity 16: 240-247.

Pavlish, L. A. and Banning, E. B. 1980 Revolutionary developments in carbon-14 dating. American Antiquity 45(2): 290-297.

Pavlish, L. A. and Sheppard, P. J. 1983 Thermoluminescent determination of Paleoindian heat treatment in Ontario, Canada. American Antiquity 48(4): 793799.

Pearson, G. W., Pilcher, J. R., Baille, M. G., Corbett, D. M. and Qua, F. 1986 High-precision radiocarbon measurement of Irish oaks to show the natural ${ }^{14} \mathrm{C}$ variations from $\mathrm{AD} 1840$ to 5210 BC. In Stuiver, M. and $\mathrm{Kra}$, R. S., eds., Proceedings of the 12 th International ${ }^{14} \mathrm{C}$ Conference. Radiocarbon 28(2B): 911934.

Pearson, G. W. and Stuiver, M. 1986 High-precision calibration of the radiocarbon time scale, 500-2500
BC. In Stuiver, M. and Kra, R. S., eds., Proceedings of the 12 th International ${ }^{14} \mathrm{C}$ Conference. Radiocarbon 28(2B): 839-862.

Platcek, E. P. 1965 Preliminary survey of a Fowl Lakes site. Minnesota Archaeologist XXVII(2): 21-92.

Purdy, B. 1982 Pyrotechnology: Prehistoric application to chert materials in North America. In Wertime, T. A. and Wertime, S. F., eds., Early Pyrotechnology. Washington, D.C., Smithsonian Institution Press: 31-44.

Renfrew, C. 1973 Before Civilization: The Radiocarbon Revolution and Prehistoric Europe. New York, Alfred A. Knopf.

Ritzenthaler, R. E. and Wittry, W. L. 1952 The Oconto site-an Old Copper manifestation. Wisconsin Archae. ologist 33: 199-223.

Stuiver, M., Kromer, B., Becker, B. and Ferguson, C. W. 1986 Radiocarbon age calibration back to 13,300 Years $\mathrm{BP}$ and the ${ }^{14} \mathrm{C}$ age matching of the German oak and US bristlecone pine chronologies. In Stuiver, M. and Kra, R. S., eds., Proceedings of the 12th International ${ }^{14} \mathrm{C}$ Conference. Radiocarbon $28(2 \mathrm{~B})$ : 969-979.

Tylecote, R. F. 1987 The Early History of Metallurgy in Europe. New York, Longman: 90 p.

West, G. A. 1929 Copper - Its mining and use by aborigines of the Lake Superior Region. Public Museum of Milwaukee Bulletin 10: 1-184.

1932 Exceptional prehistoric implements. Public Museum of Milwaukee Bulletin 10: 377-400.

Wilson, G. C., Rucklidge, J. C., Kieser, W. E. and Beukens, R. P. 1984 Development of an ion microprobe stage for accelerator mass spectrometry. In Wölfli, W., Polach, H. A. and Anderson, H. H., eds., Proceedings of the 3rd International Symposium on Accelerator Mass Spectrometry. Nuclear Instruments and Methods 233 B5(2): 200-203.

Wittry, W. L. 1951 A preliminary study of the Old Copper Complex. The Wisconsin Archaeologist 32: $1-18$. 